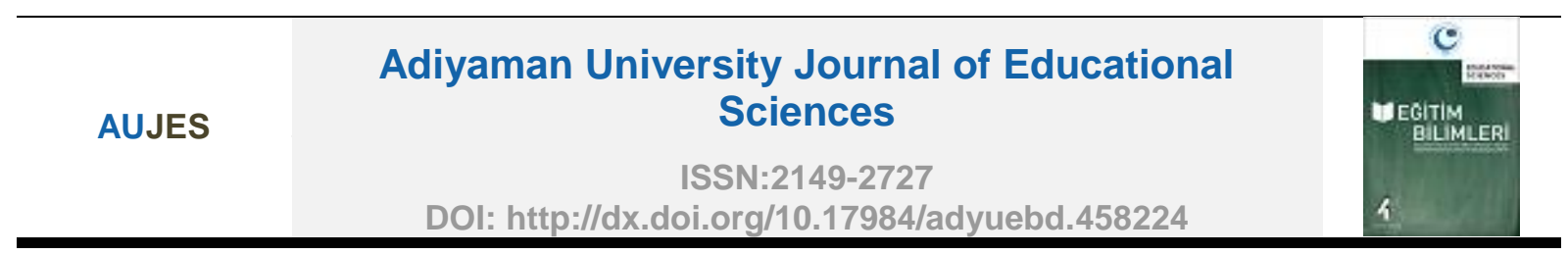

\title{
The Relationship between Psychological Well-Being and Psychological Resilience Levels of Parents and Social Competence and Behaviors of Children*
}

\author{
Zeynep KINDIROĞLU1, Fatma YAŞAR EKICi²**
}

${ }^{1}$ Istanbul Sabahattin Zaim University, Institute of Social Sciences, Turkey

${ }^{2}$ Istanbul Sabahattin Zaim University, Institute of Social Sciences, Turkey

\section{ARTICLE INFO}

\section{Article History:}

Received

08.09.2018

Received in revised form 18.04.2019

Accepted

10.05.2019

Available online

30.06.2019

Article Type:

Research Article

\begin{abstract}
The main purpose of this study was to examine the relationship between psychological well-being and psychological resilience levels of parents, and social competence and behaviors of children. Within the scope of this main purpose, it was examined whether there is a significant relationship between psychological well-being and psychological resilience levels of parents, between psychological well-being levels of parents and social competence and behaviors of their children, and between psychological resilience levels of parents and social competence and behaviors of their children. The sample of this study conducted in the relational screening model and choosed by simple random sampling method consists of 300 children aged between 3-6 years who are studying in 8 state preschool institutions located in 4 districts of Istanbul province (Şişli, Küçükçekmece, Avcılar, Üsküdar) during the 2017-2018 academic year and their parents. The Personal Information Form, Psychological Well-Being Scale, Psychological Resilience Scale for Adults and Social Competence and Behavior Evaluation-30 Scale were used as data collection tools. Statistical analyses of the obtained research data were carried out using the Spearman Rank-Order Correlation Analysis, Kruskal-Wallis H Test and Mann-Whitney U Test in IBM SPSS Statistics 22 program. At the end of the research, it was determined that there was a significant relationship between psychological well-being and psychological resilience levels of parents, and the social competence and behaviors of their children

(C) 2019 AUJES. All rights reserved

Keywords: Preschool, Psychological Well-being, Psychological Resilience, Social Competence
\end{abstract}

\section{Extended Abstract}

\section{Purpose}

Psychological resilience is the adaptability of the person to change in his life during the dynamic process that results from the interaction of protective factors and risk factors when faced with adversity (migration, divorce, natural disasters, poverty, dysfunctional family, etc.) (Karaırmak, 2006: 130). Another concept closely related to psychological resilience is the

\footnotetext{
${ }^{*}$ This article is produced from a part of the master thesis of Zeynep Kındıroğlu supervised by Dr. Fatma YAŞAR EKICI.

** Corresponding author's address: İstanbul Sabahattin Zaim University, İstanbul. e-mail: fatmayasarekici@hotmail.com
} 
concept of 'psychological well-being.' Psychological well-being means the positive perception of self, self-satisfaction even when the person is aware of his/her limitations, developing safe relationships with others and shaping the environment to meet his/her individual desires and needs, being able to act autonomously and independently, having an objective and life purpose, and trying to improve his/her capacity with the awareness of his/her capacity (Keyes, Shmotkin ve Ryff, 2002). Psychological resilience and psychological well-being of parents are influential on their children's social competence and behaviors. Social competence is the ability of the individual to have social competence or to show competent social behaviors as a result of directing himself/herself and his/her social relations (Çorbacı-Oğuz, 2008). When the studies were examined, there were studies that examine psychological well-being and psychological resilience, and social competence and behaviors according to various dependent and independent variables. However, there was no study that examines the relationship between psychological well-being and psychological resilience levels of parents, and social competence and behaviors of children. Therefore, the main purpose of this study was to examine 'the relationship between psychological well-being and psychological resilience levels of parents, and social competence and behaviors of children.'

\section{Method}

The sample of this study conducted in the relational screening model and choosed by simple random sampling method consists of 300 children aged between 3-6 years who are studying in 8 state preschool institutions located in 4 districts of Istanbul province (Şişli, Küçükçekmece, Avcılar, Üsküdar) during the 2017-2018 academic year and their parents. The Personal Information Form, Psychological Well-Being Scale, Psychological Resilience Scale for Adults and Social Competence and Behavior Evaluation-30 Scale were used as data collection tools. Statistical analyses of the obtained research data were carried out using the Spearman Rank-Order Correlation Analysis, Kruskal-Wallis H Test and Mann-Whitney U Test in IBM SPSS Statistics 22 program.

\section{Results}

At the end of the research, it was determined that there was a significant relationship between psychological well-being and psychological resilience levels of parents, and the social competence and behaviors of their children Accordingly, as the psychological well-being levels of parents increase, their psychological resilience levels for the perception of self, the perception of future, structured style, social competence, family cohesion, and social resources increase. There was a significant relationship between the psychological well-being levels of parents, and the social competence and behaviors of their children. Accordingly, as the psychological well-being levels of parents increase, the social competence levels of their children increase and their anxiety-withdrawal and anger-aggression levels decrease. There 
was a significant relationship between the psychological resilience levels of parents and the social competence and behaviors of their children. Accordingly, as the psychological resilience levels of parents for the perception of self, the perception of future, structured style, social competence, family cohesion, and social resources increase, the social competence levels of their children increase, and their anxiety-withdrawal levels decrease. Furthermore, as the psychological resilience levels of parents for the perception of self, the perception of future, structured style, social competence, family cohesion, and social resources increase, their anger-aggression levels decrease. In contrast, no significant relationship was determined between the psychological resilience levels of parents for social competence and the angeraggression levels of their children.

\section{Discussion and Conclusion}

As a result of this study, the psychological well-being and psychological resilience levels of parents, and the social competence and behaviors of their children were determined to have a significant relationship. This result, which was obtained from the study, can be interpreted as the fact that the "social problem-solving skills, life satisfaction, working and childbearing and personality traits of parents" may affect their psychological well-being and psychological resilience levels, and this situation may be reflected in the social competence and behaviors of their children. As a matter of fact, in the study conducted by Durmuş (2016), it was determined that the social problem-solving skills of adult individuals affect their psychological resilience. In the study carried out by Güler-Yazıcı (2017), it was found out that as individuals' life satisfaction increases, their psychological resilience increases; as their loneliness level increases, their psychological resilience decreases. Moreover, it was determined in the same study that life satisfaction and loneliness variables explain the structured style, perception of future, family cohesion, perception of self, social competence, social resources sub-dimensions and total psychological resilience levels of adults. In the study by Yılmaz (2017), the psychological resilience levels of working women who have a child were found to be higher compared to both working women who do not have a child and non-working women who have a child. In addition, the psychological resilience levels of non-working women who do not have a child were found to be higher compared to both working women who do not have a child and non-working women who have a child. In the study by Topçu (2017), as the neuroticism personality traits of individuals increase, their psychological resilience levels decrease; as extroversion, openness to experience, openness, amiability and responsibility personality traits of individuals increase, their psychological resilience levels increase.

Considering that the family is the smallest building block that constitutes the society, the studies aimed at improving and strengthening the families will also improve and strengthen the society. In this context, effective policies should be developed and implemented to increase 
the psychological well-being and psychological resilience of families by the institutions and organizations responsible for providing services to the society such as the relevant ministries, health institutions, non-governmental organizations, educational institutions, and municipalities. In schools, which are the most effective organizations after the family in the shaping of children's social competence and behaviors, the school and family cooperation should be provided by organizing family education and family participation activities related to the subject, and in this way, families should be provided with an effective and conscious role in the social development of their children. 


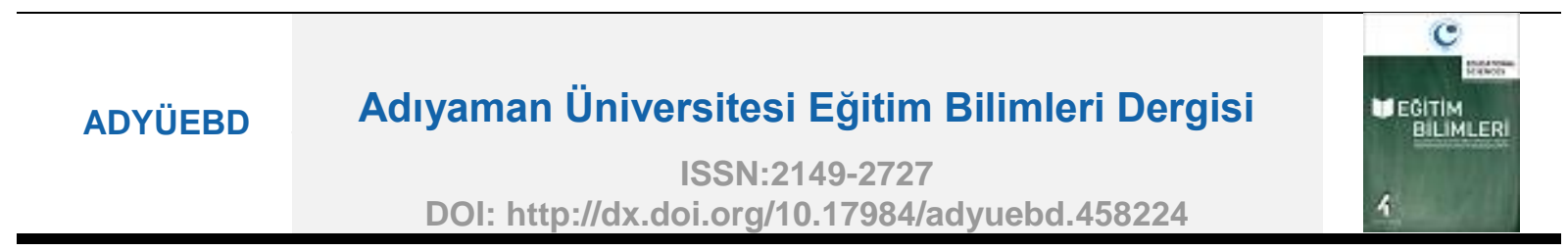

\section{Ebeveynlerin Psikolojik İyi Oluş ve Psikolojik Dayanıklılık Düzeyleri ile Çocukların Sosyal Yetkinlik ve Davranışları Arasındaki İlişki*}

\section{Zeynep KINDIROĞLU1, Fatma YAŞAR EKICi2**}

${ }^{1}$ İstanbul Sabahattin Zaim Üniversitesi, Sosyal Bilimler Enstitüsü, Türkiye

${ }^{2}$ İstanbul Sabahattin Zaim Üniversitesi, Sosyal Bilimler Enstitüsü, Türkiye (iD)

MAKALE BÍLGI

Makale Tarihcesi:

Alındı 08.09.2018

Düzeltilmiş hali

alındı 18.04.2019

Kabul edildi

10.05.2019

Çevrimiçi

yayınlandı

30.06.2019

Makale Türü:

Araştırma Makalesi

\section{ÖZET}

Bu araştırmanın temel amacı, ebeveynlerin psikolojik iyi oluş ve psikolojik dayanıklılık düzeyleri ile çocukların sosyal yetkinlik ve davranışları arasındaki ilişkiyi incelemektir. Bu temel amaç çerçevesinde, ebeveynlerin psikolojik iyi oluş düzeyleri ile psikolojik dayanıklılık düzeyleri arasında, ebeveynlerin psikolojik iyi oluş düzeyleri ile çocuklarının sosyal yetkinlik ve davranışları arasında, ebeveynlerin psikolojik dayanıklılık düzeyleri ile çocuklarının sosyal yetkinlik ve davranışları arasında anlamlı bir ilişki olup olmadığı araştırılmıştır. İlişkisel tarama modelindeki bu araştırmanın örneklemini 2017-2018 eğitim-öğretim yılında İstanbul ilindeki 4 ilçede (Şişli, Küçükçekmece, Avcılar, Üsküdar) yer alan 8 devlet okul öncesi eğitim kurumunda eğitim görmekte olan 3-6 yaş grubu 300 çocuk ve ebeveynleri oluşturmaktadır. Araştırmada veri toplama aracı olarak Kişisel Bilgi Formu, Psikolojik İyi Oluş Ölçeği, Yetişkinler İçin Psikolojik Dayanıklılık Ölçeği ve Sosyal Yetkinlik ve Davranış Değerlendirme-30 Ölçeği kullanılmıştır. Elde edilen araştırma verilerinin istatiksel çözümlemeleri IBM SPSS Statistics 22 programında Spearman Sıra Farkları Korelasyon Analizi, Kruskal Wallis $\mathrm{H}$ Testi ve Mann Whitney U Testi kullanılarak analiz edilmiştir. Araştırma sonucunda ebeveynlerin psikolojik iyi oluş düzeyleri ve psikolojik dayanıklılık düzeyleri ile çocuklarının sosyal yetkinlik ve davranışları arasında anlamlı ilişki olduğu saptanmıştır.

(C) 2019 AUJES. Tüm hakları saklıdır

Anahtar Kelimeler: Okulöncesi, Psikolojik İyi Oluş, Psikolojik Dayanıklılık, Sosyal Yetkinlik

\section{Giriş}

Aile, sosyal çevre gibi çok yönlü ilişki yapısına sahip olan insan, koşullara uyum sağlayarak yaşamını devam ettirme gayretindedir. Algılanan destek, bireylerin hayatlarına devam etmelerini sağlayan önemli etkenlerden biridir. Hayat boyunca vefatlar, işsiz kalma, aile ve sağlık gibi konularda sorunlar ortaya çıkabilmekte, bireyler bu sorunların üstesinden gelemediğinde psikosomatik rahatsızlıklarla karşılaşabilmektedir. Amaçları doğrultusunda hayata tutunan kişiler ise, ortaya çıkan bu sorunlar karşısında onların üstesinden gelebilecek düşüncelerle yaşamına devam edebilenlerdir. Sorunların üstesinden gelmeyi temsil eden düşünceler, 'kendini

\footnotetext{
* Bu makale, Zeynep Kındıroğlu'nun Dr. Öğr. Üyesi Fatma YAŞAR EKiCi'nin danışmanlığında hazırlamış olduğu yüksek lisans tezinin bir bölümünden üretilmiştir.

** Sorumlu yazarın adresi: İstanbul Sabahattin Zaim Üniversitesi, İstanbul. e-mail: fatmayasarekici@hotmail.com
} 
toparlama gücü' bir diğer ifadeyle 'psikolojik dayanıklılık' (resilience) ile ifade edilmektedir. Psikolojik dayanıklılık, bir olumsuzluk durumu (boşanma, terör, doğal afetler, yoksulluk, bozuk aile düzeni, hatta şehir değiştirme ya da taşınma) ile karşı karşıya kalındığında koruyucu faktörler ile risk faktörlerinin etkileşimi sonucu ortaya çıkan dinamik süreç içerisinde, kişinin hayatındaki değişikliğe uyum göstermesidir (Karaırmak, 2006: 130). Psikolojik dayanıklılık seviyesi yüksek olan kişiler, ileriye yönelik organizasyonel süreçleri uyumla karşılayabildikleri için daha az sorun yaşarlar (Klag ve Bradley, 2004). Sorunla karşılaştıklarında ise, bu süreci gelişim yolculuklarının basamağı olarak düşünerek kontrol altına almak için derhal harekete geçerler (Hanton ve diğ., 2002). Psikolojik dayanıklılıkla yakından ilişkili olan bir diğer kavram da 'psikolojik iyi oluş' kavramıdır. Psikolojik iyi oluş; bireyin kendini olumlu algılamasını, sınırlılıklarının farkında olduğunda bile kendinden memnun olmasını, diğerleriyle güvenli ilişkiler geliştirmesini, kişisel istek ve intiyaçlarını karşılayacak şekilde çevresini şekillendirmesini, özerk ve bağımsız hareket edebilmesini, yaşam amacının ve anlamının olmasını, kapasitesinin farkında olarak kapasitesini geliştirmeye çalışmasını ifade etmektedir (Keyes, Shmotkin ve Ryff, 2002).

Sosyal yetkinlik, bireyin kendi kendini ve sosyal ilişkilerini yönetmesi sonucu sosyal yeterliğe sahip olması ya da yeterli sosyal davranışlar sergilemesidir (ÇorbacıOğuz, 2008). Sosyal yetkinlik, genel anlamıyla sosyal ilişkilerde başarı, arkadaşlık gibi çevresel göstergelere ve bireylerin sahip oldukları bazı becerilere göre farklı şekillerde değerlendirilmektedir (Rose-Krasnor, 1997). Erken çocukluk döneminde sosyal açıdan yetkin bir çocuğun; ebeveyni ile duygusal yönden güçlü bağlar kurması, yetişkinlerle ve akranlarıyla olumlu ilişkiler kurabilmesi, özgüvene sahip olması, paylaşması, yardımlaşması ve işbirliği yapması beklenmektedir (Gresham ve Reschly, 1987; Hartup, 1996; Slaski ve Cartwright, 2002; Thompson, 2006; Verschueren, Buyck ve Marcoen, 2001). Çocuğun sosyal yetkinlik ve davranışı, etkileşimde bulunduğu iki grubun, ailenin ve akranların tepkileri bağlamında ele alınmaktadır (Işık, 2007). Çocuğun gelişimi üzerinde en etkili sosyal çevre ailedir. Bu bağlamda, aile içinde anne babaların ebeveynlik rollerini sağlıklı bir şekilde yerine getirmeleri gerektiği söylenebilir. Bu da anne-babaların psikolojik iyi oluş ve psikolojik dayanıklılık düzeylerinin yüksek olması ile mümkün olacaktır.

Konuyla ilgili yapılan araştırmalar incelendiğinde; psikolojik iyi oluş düzeyinin (Arıcı, 2011; Armsden \& Greenberg 1987; Brown \& Ryan, 2003; Cenkseven, 2004; Deci \& Ryan 2008; Deniz, Erus ve Büyükcebeci, 2017; Erdem ve Kabasakal, 2015; Gülyüksel-Akdağ ve Cihangir-Çetinkaya, 2015; Karabacak, 2016; Karabacak, 2017; Keleş, 2017; Keyes, Shmotkin, \& Ryff, 2002; Kuyumcu, 2012; Telef, Uzman ve Ergün, 2013; Ryff, 1995; Ulu, 2018) ve psikolojik dayanıklııı düzeyinin (Ağırkan ve Kağan, 2017; Bitmiş, Sökmen ve Turgut, 2013; Bonnano, Galea, Bucciarelli, Vlahov, 2007; Erarslan, 2014; Ergün-Başak, 2012; Kılıç,2014; Karaırmak ve Siviş-Çetinkaya, 2011; Neff \& McGehee, 2010; Ong, Bergeman, Bisconti \& Wallace, 2006; Sağ, 2016; Souri ve Hasanirad, 2011; Staudinger, Freund, Linden \& Maas, 1999). çeşitli bağımlı ve bağımsız değişkenlere göre incelendiği çok sayıda araştırmaya rastlanmıştır. 
Bunun yanında; okul öncesi dönem çocuklarının sosyal yetkinlik ve davranışlarını çeşitli bağımlı ve bağımsız değişkenlere göre inceleyen araştırmalara rastlanmıştır (Altay ve Güre, 2012; Altun-Nalbant, 2016; Bozkurt, 2016; ÇiftçiTopaloğlu, 2013; Dedeoğlu, 2018; Durmuşoğlu-Saltalı ve Arslan, 2012; Gözübüyük, 2015; İlhan, 2017; Karadeniz-Akdoğan, 2017; Kotler ve McMahon, 2002; ÖnerenŞendil, 2010; Olcay, 2008; Yaşar-Ekici, 2017;). Fakat ebeveynlerin psikolojik iyi oluş ve psikolojik dayanıklılı düzeyleri ile çocukların sosyal yetkinlik ve davranışları arasındaki ilişkiyi inceleyen herhangi bir çalışmaya rastlanmamıştır. Bu nedenle bu çalışmanın problem cümlesi "ebeveynlerin psikolojik iyi oluş ve psikolojik dayanıklılık düzeyleri ile çocukların sosyal yetkinlik ve davranışları arasındaki ilişki” olarak belirlenmiştir.

\section{Yöntem}

\section{Araştırma Modeli}

Bu araştırmada ilişkisel tarama modeli kullanılmıştır. Tarama modeli, geçmişte veya halen var olan bir olayı/durumu olduğu şekli ile betimlemeyi amaç edinen araştırma türüdür (Karasar, 2017: 109). İlişkisel tarama modelleri, iki ya da daha çok değişken arasında birlikte değişimin varlığını ve/veya derecesini belirlemeyi amaçlayan araştırma modelleridir (Karasar, 2017: 14).

\section{Evren ve Örneklem}

Bu araştırmanın evrenini 2017-2018 eğitim ve öğretim yılında İstanbul ilindeki devlet okul öncesi eğitim kurumlarında eğitim görmekte olan 3-6 yaş grubu çocuklar ve ebeveynleri oluşturmuştur.

Araştırmanın örneklemini ise; basit tesadüfi örnekleme yoluyla seçilmiş 20172018 eğitim-öğretim yılında İstanbul ilindeki 4 ilçede (Şişli, Küçükçekmece, Avcılar, Üsküdar) yer alan 8 devlet okul öncesi eğitim kurumunda eğitim görmekte olan 3-6 yaş grubu 300 çocuk ve ebeveynleri oluşturmaktadır. Örneklemde yer alan çocukların \%51,3'ü (154) kız, \%48,3'ü (145) erkektir. Çocukların \%1,6'sı (5) 3 yaşında, \%18,3'ü (55) 4 yaşında, \%56,7'si (170) 5 yaşında ve \%23,4'ü (70) 6 yaşındadır.

\section{Veri Toplama Araçları}

Araştırmada veri toplama aracı olarak Kişisel Bilgi Formu, Psikolojik İyi Oluş Ölçeği (PiOÖ), Yetişkinler İçin Psikolojik Dayanıklııı Ölçeği (PDÖ) ve Sosyal Yetkinlik ve Davranış Değerlendirme-30 Ölçeği (SYDDÖ) kullanılmıştır.

Kişisel Bilgi Formu: Bu form araştırmacılar tarafından hazırlanmıştır. Formda, ebeveynler ve çocuklarına ilişkin (ebeveynin cinsiyeti, anaokuluna devam eden çocuğun cinsiyeti, kaç çocuğa sahip olduğu, evlilik süresi, annenin çalışma durumu, annenin çalıştığı kurum türü, gelir düzeyi, annenin fiziksel veya psikolojik hastalığının olup olmaması durumu, babanın fiziksel ya da psikolojik hastalığının olup olmaması) kapalı uçlu sorular yer almaktadır.

Psikolojik lyi Oluş Ölçeği (PiOÖ): Ölçek, Diener ve arkadaşları (2009, 2010) tarafından geliştirilmiştir. Ölçeğin Türkçeye uyarlama, geçerlik ve güvenilirlik çalışmaları Telef (2013) tarafından yapılmıştır. Geçerlik güvenilirlik analizleri 
çerçevesinde yapılan açımlayıcı faktör analizi sonunda, toplam açıklanan varyansın \%42 olduğu saptanmıştır. Ölçek maddelerinin faktör yükleri .54 ile .76 arasında hesaplanmıştır. Doğrulayıcı faktör analizinde uyum indeksi değerleri RMSEA $=0.08$, $\mathrm{SRMR}=0.04, \mathrm{GFI}=0.96, \mathrm{NFI}=0.94, \mathrm{RFI}=0.92, \mathrm{CFI}=0.95$ ve $\mathrm{IFI}=0,95$ olarak bulunmuştur. Ölçeğin güvenirlik çalışmasında elde edilen Cronbach alfa iç tutarlılık katsayısı .80 olarak hesaplanmıştır. Test tekrar test sonucuna göre ölçeğin birinci ve ikinci uygulaması arasında yüksek düzeyde, pozitif ve anlamlı ilişki olduğu görülmüştür ( $r=0.86, p<.01)$. Psikolojik İyi Oluş Ölçeğinin madde toplam korelasyonlarının .41 ile .63 arasında değişiklik gösterdiği ve t-değerlerinin anlamlı olduğu saptanmıştır $(p<.001)$. Ölçek, bireyin kendisi tarafından doldurulmaktadır. Psikolojik İyi Oluş Ölçeğinin maddeleri, kesinlikle katılmıyorum (1) ile kesinlikle katılıyorum (7) şeklinde 1-7 arasında cevaplanmaktadır. Bütün maddeler olumlu şekilde ifade edilmektedir. Ölçekte ters puanlanan madde bulunmamaktadır. Yüksek puan, kişinin birçok psikolojik kaynak ve güce sahip olduğunu gösterir (Telef, 2013: 376).

Yetişkinler için Psikolojik Dayanıklılık Ölçeği (PDÖ): Ölçek, Friborg ve arkadaşları (2003) tarafından geliştirilmiştir. Ölçeğin Türkçeye uyarlama, geçerlik ve güvenilirlik çalışması Basım ve Çetin (2011) tarafından yapılmıştır. Yapılan doğrulayıcı faktör analizleri sonucunda 6 faktörlü ve 33 maddeden oluşan bir yapı ortaya çıkmıştır. Boyutlar ve ölçtüğü maddeler; Kendilik Algısı (1,7,13,19,28,31), Gelecek Algısı $(2,8,14,20)$, Yapısal Stil $(3,9,15,21)$, Sosyal Yeterlilik $(4,10,16,22,25,29)$, Aile Uyumu $(5,11,17,23,26,32)$, Sosyal Kaynaklar $(6,12,18,24,27,30,33)$ şeklindedir. Ölçeğin güvenilirliğini test etmek için yapılan iç tutarlılık analizi sonucunda; Cronbach Alpha değeri .86 olarak hesaplanmıştır. Test tekrar test uygulaması sonucunda ise alt boyut değerleri Kendilik Algısı .72, Gelecek Algısı .75, Yapısal Stil .68, Sosyal Yeterlilik .78, Aile Uyumu .81, Sosyal Kaynaklar .77 şeklinde bulunmuştur. Ölçek 5'li likert tipindedir. Puanlar arttıkça dayanıkılığın artması isteniyorsa, cevap kutucuklarının soldan sağa 1, 2, 3, 4, 5 olarak değerlendirilmesi gerekir. Bu görüş dikkate alındığında ölçekteki; 1 , $3,4,8,11,12,13,14,15,16,23,24,25,27,31,33$ numaralı sorular ters puanlanır. Puan arttıkça dayanıkılığın azalması isteniyorsa cevap kutucuklarının $5,4,3,2,1$ şeklinde değerlendirilir ve bu durumda kalan maddeler ters puanlanır (Basım ve Çetin, 2011).

Sosyal Yetkinlik ve Davranış Değerlendirme Ölçeği-30(SYDDÖ): Ölçek, LaFreniere ve Dumas (1996) tarafından geliştirilmiştir. Ölçeğin Türkçe uyarlaması, geçerlilik ve güvenilirlik çalışması Çorapçı ve diğerleri (2010) tarafından yapılmıştır. Bu ölçek, okul öncesi dönemdeki çocukların, sorun belirtileri ile sosyal becerilerinin niceliğini değerlendiren 30 maddeden oluşmaktadır. "Sosyal Yetkinlik" (10 madde), "Kızgınlık-Saldırganlık" (10 madde) ve "Anksiyete-İçe dönüklük" (10 madde) olmak üzere üç alt ölçeğe sahiptir. "Sosyal Yetkinlik" alt ölçeği, çocukların akranlarıyla bir aradayken gösterdikleri iş birliği ve anlaşmazlıklara çözüm yolları aramak gibi olumlu özellikleri ölçmektedir. "Kızgınlık-Saldırganlık" alt ölçeği, yetişkinlere karşı gelme ve akran ilişkilerinde uyumsuz ve saldırgan davranmak gibi dışsallaştırma sorun belirtilerini değerlendirmektedir. "Anksiyete-i̇çe dönüklük" alt ölçeği ise çocukların üzgün, depresif duygu durumlarını ve grup içinde çekingenlik göstermek gibi içselleştirme sorun belirtilerini ölçmektedir. Ölçeğin Cronbach Alfa iç tutarlılık 
katsayıları; "Sosyal Yetkinlik" alt ölçeği için .88, "Kızgınlık-Saldırganlık" alt ölçeği için .87 "Anksiyete-İçe dönüklük” alt ölçeği için. 84'tür. Ölçeğin Test-tekrar Test Katsayıları "Sosyal Yetkinlik" alt ölçeği için .71, "Kızgınlık-Saldırganlık" alt ölçeği için .64 "Anksiyete-İçe dönüklük” alt ölçeği için. 45’tir. Ölçek, 4'lü likert tipindedir (Hiçbir zaman=1, Bazen=2, Sık Sık=3, Her zaman=4). Ölçek, çocukların öğretmenleri tarafından doldurulmaktadır. Ölçek puanlanırken her bir alt boyuta ait maddelerden elde edilen puan toplanır. Ölçekten genel bir sosyal yetkinlik ve davranış puanı hesaplanmamaktadır. Ölçek maddelerinde ters puanlanan madde yer almamaktadır (Çorapçı ve diğ., 2010).

Araştırmada kullanılan ölçeklerin güvenirlik analizlerinin saptanması amacıyla Cronbach's Alfa katsayısı hesaplanmıştır. Ölçeklerin güvenilirlik değerlerine ilişkin bilgiler Tablo 1'de sunulmuştur.

Tablo 1.PDÖ, PIOÖ ve SYDDÖ'nün Puanlarının Güvenirlik Analizi Sonuçları

\begin{tabular}{clcc}
\hline & & $\mathrm{n}$ & \multicolumn{2}{c}{ Cronbach's Alpha } \\
\hline PIOÖ & & 300 &, 901 \\
& & 300 &, 580 \\
\multirow{5}{*}{ PDÖ } & Kendilik Algısı & 300 &, 496 \\
& Gelecek Algısı & 300 &, 281 \\
& Yapısal Stil & 300 &, 566 \\
& Sosyal Yeterlilik & 300 &, 641 \\
& Aile Uyumu & 300 &, 665 \\
& Sosyal Kaynaklar & 300 &, 788 \\
\multirow{2}{*}{ SYDDÖ } & Sosyal Yetkinlik & 300 &, 708 \\
& Kaygı-Geri Çekilme & 300 &, 799 \\
& Öfke-Agresyon & &
\end{tabular}

Tablo 1'de görüldüğü üzere, Psikolojik İyi Oluş Ölçeğinin Cronbach's Alfa katsayısı ,901 olarak hesaplanmıştır. Psikolojik Dayanıklılık Ölçeğinin Kendilik Algısı alt boyutunun Cronbach's Alfa katsayısı ,580, Gelecek Algısı alt boyutunun Cronbach's Alfa katsayısı ,496, Yapısal Stil alt boyutunun Cronbach's Alfa katsayısı ,281, Sosyal Yeterlilik alt boyutunun Cronbach's Alfa katsayısı ,566, Aile Uyumu alt boyutunun Cronbach's Alfa katsayısı,641 ve Sosyal Kaynaklar alt boyutunun Cronbach's Alfa katsayısı ,665 olarak hesaplanmıştır. SYDDÖ 'nün alt boyutlarından Sosyal Yetkinlik alt boyutu Cronbach's Alfa katsayısı ,788, Kaygı-Geri Çekilme alt boyutu Cronbach's Alfa katsayısı ,708 ve Öfke-Agresyon alt boyutu Cronbach's Alfa katsayısı ,799 olarak hesaplanmıştır. Cronbach's Alfa katsayısının 0-1 arasında değiştiği, değerlendirme kriterlerine göre ".00<.40 ise ölçek güvenilir değil, . $40<.60$ ise ölçek düşük güvenirlikte, $.60<.80$ ise ölçek oldukça güvenilir ve, $80<1.00$ ise ölçek yüksek derecede güvenilir bir ölçek" olarak değerlendirildiği ifade edilmektedir (Tavşancıl, 2005). Buna göre Psikolojik İyi Oluş Ölçeği yüksek derecede güvenilir, Sosyal Yetkinlik Ölçeği alt boyutlarından Sosyal Yetkinlik, Kaygı-Geri Çekilme ve Öfke-Agresyon oldukça güvenilirdir. Psikolojik Dayanıklılık Ölçeği'nin Yapısal Stil alt boyutunun güvenilir olmadığı görülürken, Kendilik Algısı, Gelecek Algısı, Sosyal Yeterlilik alt boyutlarının 
düşük güvenilirlikte, Aile Uyumu ve Sosyal Kaynaklar alt boyutlarının ise güvenilir olduğu görülmektedir.

\section{Verilerin Toplanması}

Araştırma verilerinin toplanmasında öncelikle Psikolojik İyi Oluş Ölçeği, Yetişkinler İçin Psikolojik Dayanıkılık Ölçeği ve Sosyal Yetkinlik ve Davranış Değerlendirme-30 Ölçeği için mail yoluyla kullanım izni alınmıştır. Ardından, İstanbul İ Milli Eğitim Müdürlüğü'nden uygulama için gerekli resmi izinler alınmıştır. Veri toplama araçları, örneklemde yer alan okul öncesi dönem çocuklarının eğitim görmekte oldukları kurumlardaki öğretmenler aracılığıyla ebeveynlerine ulaştırılarak uygulanmıştır. Ebeveynler tarafından doldurulan formlar yine öğretmenler aracılığıyla geri toplanmış ve 300 veri toplama aracı analize dahil edilmiştir.

\section{Verilerin Çözümlenmesi}

Elde edilen araştırma verilerinin istatiksel çözümlemeleri IBM SPSS Statistics 22 programında uygun istatiksel işlemler yapılarak gerçekleştirilmiştir. Verilerin çözümlenmesinde öncelikle dağılımın normalliği Kolmogrov-Smirnov Testi ile tespit edilmiştir. Dağılımın normal olmadığı belirlenmiş ve bu nedenle analizlerde nonparametrik testlerden olan Spearman Sıra Farkları Korelasyon Analizi, Kruskal Wallis $\mathrm{H}$ Testi ve Mann Whitney $U$ Testi kullanılmıştır.

Dağılımın normalliğine ilişkin Yapılan Kolmogorov Smirnov Testi sonuçları Tablo 2'de sunulmuştur.

Tablo 2. PDÖ, PIOÖ ve SYDDÖ'nün Dağılımının Normallik Analizi Sonuçları

\begin{tabular}{cllcc}
\hline & & \multicolumn{3}{c}{ Kolmogorov-Smirnov } \\
\cline { 3 - 5 } & & İstatistik & sd & $\mathrm{p}$ \\
\hline \multirow{2}{*}{ PIOÖ } & & 181 & 300 &, 000 \\
& Kendilik Algısı &, 073 & 300 &, 001 \\
\multirow{3}{*}{ PDÖ } & Gelecek Algısı &, 119 & 300 &, 000 \\
& Yapısal Stil &, 105 & 300 &, 000 \\
& Sosyal Yeterlilik &, 077 & 300 &, 000 \\
& Aile Uyumu &, 110 & 300 &, 000 \\
& Sosyal Kaynaklar &, 104 & 300 &, 000 \\
& Sosyal Yetkinlik &, 082 & 300 &, 000 \\
& Kaygi-Geri Çekilme &, 140 & 300 &, 000 \\
\multirow{2}{*}{ SYDDÖ } &, 127 & 300 &, 000 \\
& Öfke-Agresyon & & &
\end{tabular}

Tablo 2'de görüldüğü gibi, Psikolojik İyi Oluş Ölçeği puanlarının KolmogorovSmirnov testi sonucuna bakıldığında normal dağılım göstermediği belirlenmiştir (K$\mathrm{S}=, 181 ; \mathrm{p}<, 05)$. Psikolojik Dayanıklılık Ölçeği puanlarının Kolmogorov-Smirnov testi sonucuna bakıldığında, alt faktörlerden Kendilik Algısı (K-S=,073; $\mathrm{p}<, 05)$, Gelecek Algısı (K-S=,119; $\mathrm{p}<, 05)$, Yapısal Stil $(\mathrm{K}-\mathrm{S}=, 105 ; \mathrm{p}<, 05)$, Sosyal Yeterlilik (K-S=,077; $\mathrm{p}<, 05)$, Aile Uyumu (K-S=,641; $\mathrm{p}<, 05$ ) ve Sosyal Kaynakların (K-S=,104; $\mathrm{p}<, 05)$ normal dağıım göstermediği belirlenmiştir. Sosyal Yetkinlik ve Davranış Değerlendirme Ölçeği puanlarının Kolmogorov-Smirnov testi sonucuna bakıldığında alt faktörlerden Sosyal 
Yetkinlik (K-S=,082; $\mathrm{p}<, 05)$, Kaygı-GeriÇekilme $(\mathrm{K}-\mathrm{S}=, 140 ; \mathrm{p}<, 05)$ ve ÖfkeAgresyonun (K-S=,127; $\mathrm{p}<, 05)$ normal dağılım göstermediği belirlenmiştir.

\section{Bulgular}

Bu kısımda araştırmada elde edilen bulgulara yer verilmiştir.

Tablo 3. PIOÖ ve PDÖ'den Alınan Puanlar Arasındaki İlişkiyi Belirlemek Üzere Yapılan Spearman Sıralama Korelasyon Katsayısı Analizi Sonuçları

\begin{tabular}{|c|c|c|c|c|c|c|c|}
\hline Boyut & & $\begin{array}{l}\text { Kendilik } \\
\text { Algısı }\end{array}$ & $\begin{array}{l}\text { Gelecek } \\
\text { Algısı }\end{array}$ & $\begin{array}{l}\text { Yapısal } \\
\text { Stil }\end{array}$ & $\begin{array}{l}\text { Sosyal } \\
\text { Yeterlilik }\end{array}$ & $\begin{array}{l}\text { Aile } \\
\text { Uyumu }\end{array}$ & $\begin{array}{l}\text { Sosyal } \\
\text { Kaynaklar }\end{array}$ \\
\hline PIOÖ & $p$ & $\begin{array}{l}\text { 228 } \\
\text {,000 }\end{array}$ & $\begin{array}{l}\text { 370 } \\
\text {,000 }\end{array}$ & $\begin{array}{l}209 \\
000\end{array}$ & $\begin{array}{l}137 \\
, 018\end{array}$ & $\begin{array}{l}161 \\
, 005\end{array}$ & $\begin{array}{l}135 \\
, 019\end{array}$ \\
\hline
\end{tabular}

Tablo 3’te görüldüğü gibi, PIOÖ'den alınan puanlarla PDÖ’nün Kendilik Algısı $(r=.228 ; p<.05)$, Gelecek Algısı ( $r=.370 ; p<.05)$, Yapısal Stil $(r=.209 ; p<.05)$, Sosyal Yeterlilik $(r=.137 ; p<.05)$ ve Sosyal Kaynaklar $(r=.135 ; p<.05)$ alt boyutlarından alınan puanlar arasında istatistiksel olarak anlamlı ve pozitif yönlü bir ilişki olduğu saptanmıştır. Buna göre; ebeveynlerin psikolojik iyi oluş düzeyi arttıkça kendilik algısı, gelecek algısı, yapısal stil, sosyal yeterlilik, aile uyumu ve sosyal kaynaklar düzeyleri artmaktadır.

Tablo 4. PIOÖ ve SYDDÖ'den Alınan Puanlar Arasındaki İlişkiyi Belirlemek Üzere Yapılan Spearman Sıralama Korelasyon Katsayısı Analizi Sonuçları

\begin{tabular}{ccccc}
\hline Boyut & & Sosyal Yetkinlik & Kaygı-Geri Çekilme & Öfke-Agresyon \\
\hline \multirow{2}{*}{ PioÖ } & $r$ &, 254 &,- 143 &,- 151 \\
& $p$ &, 000 &, 013 &, 009 \\
\hline
\end{tabular}

Tablo 4'te görüldüğü gibi, PiOÖ'den alınan puanlarla SYDDÖ'nün Sosyal Yetkinlik alt boyutundan $(r=.254 ; \mathrm{p}<.05)$ alınan puanlar arasında istatistiksel açıdan anlamlı ve pozitif bir ilişki saptanmıştır. Bunun yanında Kaygı-Geri Çekilme ( $r=-.143$; $\mathrm{p}<.05$ ) alt boyutundan PIOÖ'den alınan puanlarla, SYDDÖ'nün Öfke-Agresyon ( $r=-$ $.151 ; \mathrm{p}<.05)$ alt boyutundan alınan puanlar arasında istatistiksel açıdan anlamlı ve negatif bir ilişki saptanmıştır. Yani, ebeveynlerin psikolojik iyi oluş düzeyleri arttıkça; çocuklarının sosyal yetkinlik düzeyleri artmakta, kaygı-geri çekilme ve öfke-agresyon düzeyleri azalmaktadır.

Tablo 5. SYDDÖ'den ve PDÖ'den Alınan Puanlar Arasındaki İlişkiyi Belirlemek Üzere Yapılan Spearman Sıralama Korelasyon Katsayısı Analizi Sonuçları

\begin{tabular}{lccccccc}
\hline Boyut & & $\begin{array}{l}\text { Kendilik } \\
\text { Algısı }\end{array}$ & $\begin{array}{l}\text { Gelecek } \\
\text { Algısı }\end{array}$ & $\begin{array}{l}\text { Yapısal } \\
\text { Stil }\end{array}$ & $\begin{array}{l}\text { Sosyal } \\
\text { Yeterlilik }\end{array}$ & $\begin{array}{l}\text { Aile } \\
\text { Uyumu }\end{array}$ & $\begin{array}{l}\text { Sosyal } \\
\text { Kaynaklar }\end{array}$ \\
\hline Sosyal & $\mathrm{r}$ &, 186 &, 268 &, 187 &, 167 &, 165 &, 137 \\
Yetkinlik & $\mathrm{p}$ &, 001 &, 000 &, 001 &, 004 &, 004 &, 018 \\
\hline Kaygı-Geri & $\mathrm{r}$ &,- 178 &,- 192 &,- 168 &,- 124 &,- 157 &,- 182 \\
Çekilme & $\mathrm{p}$ &, 002 &, 001 &, 004 &, 031 &, 006 &, 002 \\
\hline Öfke- & $\mathrm{r}$ &,- 141 &,- 170 &,- 171 &,- 111 &,- 163 &,- 168 \\
Agresyon & $\mathrm{p}$ &, 014 &, 003 &, 003 &, 054 &, 005 &, 004 \\
\hline
\end{tabular}


Tablo 5'te görüldüğü gibi, SYDDÖ'nün alt boyutlarından Sosyal Yetkinlik alt boyutu ile PDÖ'nün alt boyutlarından Kendilik Algısı $(r=.186 ; p<.05)$, Gelecek Algısı $(r=.268 ; p<.05)$, Yapısal Stil $(r=.187 ; p<.05)$, Sosyal Yeterlilik $(r=.167 ; p<.05)$, Aile Uyumu $(r=.165 ; p<.05)$ ve Sosyal Kaynaklar $(r=.137 ; p<.05)$ alt boyutlarından alınan puanlar arasında istatistiksel açıdan anlamlı pozitif bir ilişki bulunmuştur. Buna göre ebeveynlerin kendilik algısı, gelecek algısı, yapısal stil, sosyal yeterlilik, aile uyumu ve sosyal kaynaklara ilişkin psikolojik dayanıkılık düzeyleri arttıkça çocuklarının sosyal yetkinlik düzeyleri artmaktadır. SYDDÖ'nün alt boyutlarından Kaygı-Geri Çekilme alt boyutu ile PDÖ'nün Kendilik Algısı ( $r=-.178 ; p<.05)$, Gelecek Algısı $(r=-.192 ; p<.05)$, Yapısal Stil $(r=-.168 ; p<.05)$, Sosyal Yeterlilik $(r=-.124 ; p<.05)$, Aile Uyumu $(r=-.157$; $\mathrm{p}<.05)$ ve Sosyal Kaynaklar $(\mathrm{r}=-.182 ; \mathrm{p}<.05)$ alt boyutlarından alınan puanlar arasında istatistiksel açıdan anlamlı ve negatif bir ilişki bulunmuştur. Buna göre ebeveynlerin kendilik algısı, gelecek algısı, yapısal stil, sosyal yeterlilik, aile uyumu ve sosyal kaynaklara ilişkin psikolojik dayanıklılık düzeyleri arttıkça çocuklarının kaygı-geri çekilme düzeyleri azalmaktadır. SYDDÖ'nün Öfke-Agresyon alt boyutu ile $P D O ̈$ 'nün alt Kendilik AlgısI $(r=-.141 ; p<.05)$, Gelecek Algısı $(r=-.170 ; p<.05)$, Yapısal Stil $(r=-.171$; $\mathrm{p}<.05)$, Aile Uyumu $(\mathrm{r}=-.163 ; \mathrm{p}<.05)$ ve Sosyal Kaynaklar $(\mathrm{r}=-.168 ; \mathrm{p}<.05)$ alt boyutlarından alınan puanlar arasında istatistiksel açıdan anlamlı ve negatif ilişki bulunmuştur. Buna göre ebeveynlerin kendilik algısı, gelecek algısı, yapısal stil, aile uyumu ve sosyal kaynaklara ilişkin psikolojik dayanıklılık düzeyleri arttıkça çocuklarının öfke-agresyon düzeyleri azalmaktadır. SYDDÖ'nün Öfke-Agresyon alt boyutu ile $P D O ̈$ 'nün Sosyal Yeterlilik alt boyutu arasında istatistiksel olarak anlamlı bir ilişki olmadığı saptanmıştır ( $r=-.111 ; p>.05)$.

\section{Tartışma, Sonuç ve Öneriler}

Araştırmadan elde edilen sonuca göre ebeveynlerin psikolojik iyi oluş düzeyleri ile psikolojik dayanıklııık düzeyleri arasında anlamlı ilişki olduğu saptanmıştır. Buna göre ebeveynlerin psikolojik iyi oluş düzeyleri artııça kendilik algısına, gelecek algısına, yapısal stile, sosyal yeterliliğe, aile uyumuna ve sosyal kaynaklara yönelik psikolojik dayanıklılık düzeyi artmaktadır. Sağ (2016), yapmış olduğu araştırmada, psikolojik dayanıklıı̆ın psikolojik iyi oluş üzerinde pozitif yönde etkili olduğunu saptamıştır. Depresyon ve psikolojik iyi oluş ilişkisinde psikolojik dayanıklıı̆ın kısmi bir aracı rolü oynadığı bulunmuştur. Karaırmak ve Siviş-Çetinkaya (2011), yapmış oldukları araştırmada hem olumlu hem de olumsuz duyguların psikolojik dayanıklılığı yordadığı sonucuna varmışlardır. Akdoğan ve Yalçın (2018), yapmış oldukları araştırmada öznel iyi oluşun saldırganlık ile negatif yönde, problem çözme ile pozitif yönde anlamlı düzeyde olduğu bir ilişkiye rastlamışlardır. Aile desteği, akran desteği, okul desteği, mücadele azmi, uyum ve problem çözme boyutlarının (psikolojik dayanıkııığın alt boyutlarından) öznel iyi oluşun bir yordayıcısı oldukları sonucuna varmışlardır. Karacaoğlu ve Köktaş'ın (2016) yapmış oldukları araştırmada psikolojik olarak dayanıklı olan bireylerin, psikolojik iyi oluş düzeylerinin yüksek ve genellikle iyimser oldukları tespit edilmiştir. Ayrıca çalışanların psikolojik dayanıklıı̆ının, psikolojik iyi olma düzeylerini pozitif yönde ve anlamlı bir şekilde etkilediği, iyimserliğin 
ise bu ilişkide kısmi aracı değişken rolünü oynadığı sonucuna varılmıştır. Ülker-Tümlü ve Recepoğlu (2013), yapmış oldukları araştırmada psikolojik dayanıklılığın, yaşam doyumunun anlamlı bir yordayıcısı olduğunu bulmuşlardır. Özer ve Deniz (2014), yapmış oldukları araştırmada duygusal zekanın alt boyutu olan iyi oluşun, psikolojik sağlamlığın önemli bir yordayıcısı olduğu sonucuna varmışlardır. Terzi (2005), yapmış olduğu araştırmada psikolojik dayanıklılığın bilişsel değerlendirmede ve başa çıkma aracılığı ile psikolojik iyi olmayı dolaylı olarak etkilediği sonucuna varmıştır. Kılıç (2014), yapmış olduğu araştırmada gelecekten umutlu olma algısı ile psikolojik dayanıklıığın arasında anlamlı bir ilişki olduğunu saptamıştır. Gelecekten umutlu bireylerin psikolojik dayanıkılık puan ortalamaları, gelecekten umutlu olmayan bireylerin psikolojik dayanıklılık puan ortalamalarından anlamlı düzeyde yüksek bulunmuştur. Çelik (2016), yapmış olduğu araştırmada algılanan sosyal yetkinliğin, (psikolojik dayanıkılığın alt boyutlarından) psikolojik iyi oluşun anlamlı bir yordayıcısı olduğunu saptamıştır. Bu sonuçlardan yola çıkarak, aile üyelerinin her birinin iyi oluşunun ailenin diğer üyelerinin iyi oluşunu, aile işlevlerinin sağlıklılığını ve ailenin psikolojik dayanıkılık düzeyini doğrudan etkilediği söylenebilir.

Araştırmadan elde edilen bir diğer sonuca göre ebeveynlerin psikolojik iyi oluş düzeyleri ile çocuklarının sosyal yetkinlik ve davranışları arasında anlamlı ilişki saptanmıştır. Buna göre ebeveynlerin psikolojik iyi oluş düzeyi arttıkça çocuklarının sosyal yetkinlik düzeyleri artmakta, kaygı-geri çekilme ve öfke-agresyon düzeyleri azalmaktadır. Araştırmanın bu sonucu ile ilgili yapılmış benzer bir araştırmaya rastlanmamıştır. Araştırmanın bu sonucu, ebeveynlerin psikolojik iyi oluş düzeylerinin yüksek olmasının çocukların olumlu sosyal becerilerinin gelişimini olumlu yönde etkileyeceği; ebeveynlerin psikolojik iyi oluş düzeylerinin düşük olmasının ise çocuklarının olumsuz sosyal davranışlar sergilemelerine neden olabileceği şeklinde yorumlanabilir. Bunun yanında; ebeveynlerin psikolojik iyi oluş düzeyleri, çocuk yetiştirme tutumlarına da yansıyacaktır. Psikolojik iyi oluş düzeyi yüksek ebeveynler, çocuklarını yetiştirirken olumlu ebeveyn tutumları sergileyeceklerdir. Nitekim, Özyürek'in (2015) yaptığı araştırmada çocukların sosyal beceri düzeylerinin annelerin olumlu ebeveyn tutumlarından olan demokratik tutumlarından anlamlı ölçüde etkilendiği; demokratik tutum sergileyen annelerin çocuklarının sosyal beceri düzeylerinin diğerlerine göre daha yüksek olduğu saptanmıştır. Durmuşoğlu-Saltalı ve Arslan'ın (2012) yaptığı araştırmada çocukların sosyal yetkinlikleriyle anne babaların aşırı koruyucu ve otoriter olmaları arasında negatif yönde anlamlı bir ilişki bulunmuştur. Gözübüyük'ün (2015) yaptığı araştırmada okul öncesi dönem çocuklarında anne-baba tutumunun davranış sorunları üzerinde doğrudan etkisi olduğu; olumlu anne-baba tutumu ile çocukların davranış sorunları arasında negatif ilişkinin olduğu saptanmıştır. Psikolojik iyi oluş düzeyi düşük olan ebeveynler, olumsuz anne-babalık davranışları (sevginin geri çekilmesi, güce başvurma tehdidi, olumsuz yorumlar ve duygular, fiziksel ceza, tutarsız disiplin vb.) sergileyeceklerdir. Olumsuz anne-babalık davranışları ise saldırganlıkla bağlantılı bulunmaktadır (Berk, 2013). Anne babaların bu tür davranışları, çocukların hem fiziksel hem de sözel saldırganlık göstermelerine neden olabilir (Çiftçi-Topaloğlu, 2013). 
Araştırmanın diğer sonucuna göre ebeveynlerin psikolojik dayanıklıık düzeyleri ile çocuklarının sosyal yetkinlik ve davranışları arasında anlamlı ilişki saptanmıştır. Buna göre ebeveynlerin kendilik algısına, gelecek algısına, yapısal stile, sosyal yeterliliğe, aile uyumuna ve sosyal kaynaklara yönelik psikolojik dayanıklılık düzeyleri arttıkça çocuklarının sosyal yetkinlik düzeyleri artmakta; kaygı-geri çekilme düzeyleri azalmaktadır. Bunun yanında ebeveynlerin kendilik algısına, gelecek algısına, yapısal stile, aile uyumuna ve sosyal kaynaklara yönelik psikolojik dayanıklılık düzeyleri arttıkça öfke-agresyon düzeyleri azalmaktadır. Bundan farklı olarak ebeveynlerin sosyal yeterliliğe yönelik psikolojik dayanıklılık düzeyleri ile çocuklarının öfke-agresyon düzeyleri arasında anlamlı ilişki saptanmamıştır. Araştırmanın bu sonucu; ebeveynlerin 'sosyal problem çözme becerilerinin, yaşam doyumlarının, yalnızlık duygularının, çalışma ve çocuk sahibi olma durumlarının ve kişilik özelliklerinin' psikolojik dayanıklılık düzeylerini etkileyebileceği ve bu durumun çocukların sosyal yetkinlik ve davranışlarına yansıyabileceği şeklinde yorumlanabilir. Nitekim yapılan araştırma sonuçları bu yorumu destekler niteliktedir. Şöyle ki; Dereli-İman'ın (2013) yaptığı araştırmada yetişkinlerin sosyal problem çözme becerilerinin, okul öncesi dönem çocuklarının kavgacı-saldırgan olma, endişeli-ağlamaklı olma ve aşırı hareketlidikkatsiz olma durumlarını olumsuz yönde anlamlı düzeyde yordadığı saptanmıştır. Durmuş'un (2016) yaptığı araştırmada yetişkin bireylerin problem çözme becerilerinin psikolojik dayanıklılığı etkilediği saptanmıştır. Güler-Yazıcı (2017) yaptığı araştırmada bireylerin yaşam doyumları arttıkça psikolojik dayanıklılıklarının arttığı; yalıızıık düzeyleri arttıkça psikolojik dayanıklılıklarının azaldığı sonucuna ulaşmıştır. Bunun yanında, aynı araştırmada yaşam doyumu ve yalnızlık değişkenlerinin yetişkinlerin yapısal stil, gelecek algısı, aile uyumu, kendilik algısı, sosyal yeterlilik, sosyal kaynaklar alt boyutları ile toplam psikolojik dayanıklılık düzeylerini açıkladığı bulunmuştur. Yılmaz'ın (2017) yaptığı araştırmada çalışan ve çocuğu olan kadınların psikolojik dayanıklılıklarının, hem çalışan ve çocuğu olmayan kadınlardan hem de çalışmayan ve çocuğu olan kadınlardan daha yüksek bulunmuştur. Çalışmayan ve çocuğu olmayan kadınların psikolojik dayanıklılıkları, hem çalışan ve çocuğu olmayan kadınlardan hem de çalışmayan ve çocuğu olan kadınlardan daha yüksek bulunmuştur. Topçu'nun (2017) yaptığı araştırmada bireylerin duygusal dengesizlik kişilik özellikleri arttıkça psikolojik dayanıklılık düzeyleri azalmakta; dışadönüklük, deneyime açıklık, yumuşak başlılık ve sorumluluk kişilik özellikleri arttıkça psikolojik dayanıklııı düzeyleri artmaktadır.

$\mathrm{Bu}$ araştırmadan elde edilen sonuçlar göstermektedir ki ebeveynlerin psikolojik iyi oluş ve psikolojik dayanıklılıkları ile çocuklarının sosyal etkinlik ve davranışları birbiriyle ilişkili değişkenlerdir. Ailenin toplumu oluşturan en küçük yapı taşı olduğu dikkate alındığında ailelerin iyileştirilmesine ve güçlendirilmesine yönelik yapılacak çalışmalar, toplumun da iyileştirilmesi ve güçlendirilmesini sağlayacaktır. Bu bağlamda; ilgili bakanlıklar, sağlık kuruluşları, sivil toplum kuruluşları, eğitim kurumları ve belediyeler gibi topluma hizmet sunmakla görevli kurum ve kuruluşlarca ailelerin psikolojik iyi oluş ve psikolojik dayanıklılıklarını artırmaya yönelik etkin politikalar geliştirilip uygulamaya koyulmalıdır. Çocukların sosyal yetkinlik ve davranışlarının 
şekillenmesinde aileden sonra en etkili kurum olan okullarda konuyla ilgili aile eğitimi ve aile katılım etkinlikleri düzenlenerek okul aile işbirliği sağlanmalı ve bu şekilde aileler de çocuklarının sosyal gelişimlerinde işe koşulmalıdır. Bu araştırmada ebeveynlerin psikolojik iyi oluş ve psikolojik dayanıklılık düzeylerinin, çocuklarının sosyal yetkinlik ve davranışları ile ilişkisi incelenmiştir. Bundan sonra yapılacak araştırmalarda ebeveynlerin psikolojik iyi oluş ve psikolojik dayanıklılık düzeylerinin çocukların farklı özellikleri (zeka gelişimi, özdüzenleme becerileri, akran ilişkileri, problem çözme becerileri, özbakım becerileri vb.) ile ilişkisi incelenebilir. Aileler, zaman içinde değişen bir sistem olarak bu değişim süreci içinde çeşitli evrelerden (evlilik aşaması, çocuğa sahip olma, çocuğun ergenlik dönemine geçişi, çocukları evden ayrılması, yaşlılık ve emeklilik gibi) geçmektedir. Ailelerin bu yaşam evrelerinin her birinde psikolojik iyi oluş ve psikolojik dayanıklılık düzeylerinin ölçülerek birbiriyle karşılaştırıldığı boylamsal araştırmalar yapılabilir.

\section{Kaynaklar}

Ağırkan, M. \& Kağan, M. (2017). Üniversite öğrencilerinin değer yönelimleri ile psikolojik dayanıklılık düzeyleri arasındaki ilişki. Erzincan Üniversitesi Eğitim Fakültesi Dergisi, 19(3), 226-245. DOI: 10.17556/erziefd.335063

Akdoğan, B., \& Yalçın, S. B. (2018). Lise öğrencilerinin psikolojik dayanıklılık ve çatışma çözme davranışlarının öznel iyi oluşlarını yordaması. Mehmet Akif Ersoy Üniversitesi Eğitim Fakültesi Dergisi, 46, 174-197.

Altay, F.B., \& Güre, A. (2012). Okul öncesi kuruma (devlet-özel) devam eden çocukların sosyal yeterlik ve olumlu sosyal davranışları ile annelerinin ebeveynlik stilleri arasındaki ilişkiler. Kuram ve Uygulamada Eğitim Bilimleri, 12 ( 4), 2699-2718.

Altun-Nalbant, A. (2016). Okul öncesi eğitim kurumlarına devam eden 5 yaş çocuklarının mizaç, sosyal yetkinlik özellikleri ile çaba sarf ederek kendini denetleme becerisi arasındaki ilişkinin incelenmesi. Yüksek Lisans Tezi. Gazi Üniversitesi Eğitim Bilimleri Enstitüsü, Ankara.

Armsden, G.C. \& Greenberg, M.T. (1987). The inventory of parent and peer attachment: Individual differences and their relationship to psychological wellbeing in adolescence. Journal of Youth Adolescence, 16: 427. DOl: https://doi.org/10.1007/BF02202939

Basım, H. N., \& Çetin, F. (2011). Yetişkinler için psikolojik dayanıklılık ölçeğinin güvenilirlik ve geçerlilik çalışması. Türk Psikiyatri Dergisi, 22(2), 104-114.

Berk, L.E. (2013). Çocuk gelişimi. B. Onur (Edt.), (Çev: A. Dönmez). Ankara: İmge Kitabevi.

Bitmiş, M.G., Sökmen A. \& Turgut, H. (2013). Psikolojik dayanıklılığın tükenmişlik üzerine etkisi: Örgütsel özdeşleşmenin aracılık rolü. Gazi Üniversitesi İktisadi ve İari Bilimler Fakültesi Dergisi, 15(2), 27-40. 
Bonnano, G.A., Galea S, Bucciarelli A, \& Vlahov D. (2007). What predicts psychological resilience after disaster? The role of demographics, resources, and life stress. Journal of Consulting and Clinical Psychology, 75(5), 671-682

Bozkurt, E. (2016). Okul öncesi çocuklarının duyguları anlama becerileri ile sosyal yetkinlik düzeyleri arasındaki ilişkinin incelenmesi. Yüksek Lisans Tezi. Necmettin Erbakan Üniversitesi Eğitim Bilimleri Enstitüsü, Konya.

Brown, K. W., \& Ryan, R. M. (2003). The benefits of being present: Mindfulness and its role in psychological well-being. Journal of Personality and Social Psychology, 84(4), 822-848. DOI: http://dx.doi.org/10.1037/00223514.84.4.822

Cenkseven, F. (2004). Üniversite öğrencilerinde öznel ve psikolojik iyi olmanın yordayıcılarının incelenmesi. Doktora Tezi. Çukurova Üniversitesi Sosyal Bilimler Enstitüsü, Adana.

Çelik, O. (2016). Öğretmen adaylarında psikolojik iyi oluş algılanan sosyal yetkinlik ve güvengenliğin incelenmesi. Yüksek Lisans Tezi. Erzincan Üniversitesi, Sosyal Bilimler Enstitüsü, Erzincan.

Çiftçi-Topaloğlu, Z. (2013). 4-5 yaş çocuklarının sosyal yetkinlik, saldırganlık, kaygı düzeyleri ile anne-babalarının ebeveyn özyeterliği algısı arasındaki ilişkilerin incelenmesi. Yüksek Lisans Tezi. Pamukkale Üniversitesi Eğitim Bilimleri Enstitüsü, Denizli.

Çorapçı, F., Aksan, N., Yalçın, D. A., \& Yağmurlu, B. (2010). Okul öncesi dönemde duygusal, davranışsal ve sosyal uyum taraması: Sosyal yetkinlik ve davranış değerlendirme-30 ölçeği. Çocuk ve Gençlik Ruh Sağı̆ğı Dergisi, 17(2), 63-74.

Çorbacı-Oğuz, A. (2008). 6 yaş çocuklarında sosyal yeterliliğin, akran ilişkilerinin ve sosyal bilgi işleme sürecinin değerlendirilmesi. Doktora tezi, Ankara Üniversitesi Eğitim Bilimleri Enstitüsü, Ankara.

Deci, E.L. \& Ryan, R.M. (2008). Facilitating optimal motivation and psychological wellbeing across life's domains. Canadian Psychology, 49(1), 14-23.

Dedeoğlu, S. (2018). MEB okul öncesi eğitim programı ve Montessori programına göre eğitim alan çocukların bilişsel gelişim ve sosyal yetkinliklerinin karşılaştırmalı olarak incelenmesi. Yüksek Lisans tezi, Necmettin Erbakan Üniversitesi Eğitim Bilimleri Enstitüsü, Konya.

Deniz, M.E., Erus, S.M. \& Büyükcebeci, A. (2017). Bilinçli farkındalık ile psikolojik iyi oluş ilişkisinde duygusal zekanın aracılık rolü. Türk Psikolojik Danışma Ve Rehberlik Dergisi, 7(47), 17-31.

Dereli-İman, E. (2013). Çocuklar için sosyal problem çözme ölçeği'nin 6 yaş grubu için Türkiye uyarlaması ve okul öncesi davranış problemleri ile sosyal problem çözme becerileri arasındaki ilişkiler. Kuram ve Uygulamada Eğitim Bilimleri, 13(1), 479-498. 
Diener, E., Wirtz, D., Biswas-Diener, R., Tov, W., Kim-Prieto, C., Choi, D., et al. (2009). New measures of wellbeing. Social Indicators Research Series, 39. DOI: 10.1007/978-90-481-2354-4 12.

Diener, E., Wirtz, D., Tov, W., Kim-Prieto, C., Choi, D., Oishi, S., \& Biswas-Diener, R. (2010). New well-being measures: Short scales to assess flourishing and positive and negative feelings. Social Indicators Research, 97, 143-156.

Durmuş, M. (2016). Üniversite öğrencilerinin problem çözme becerileri ile psikolojik dayanıklılıkları arasındaki ilişki. Yüksek Lisans Tezi. Atatürk Üniversitesi Sağlık Bilimleri Enstitüsü, Erzurum.

Durmuşoğlu-Saltalı N. \& Arslan, E. (2012). Ebeveyn tutumlarının anasınıfına devam eden çocukların sosyal yetkinlik ve içe dönüklük davranışını yordaması. Ilköğretim Online, 11(3), 729-737.

Erarslan, Ö. (2014). Üniversite öğrencilerinde psikolojik sağlamlık ile depresif belirtiler ve yaşam memnuniyeti arasındaki ilişkide benlik saygısı, pozitif dünya görüşü ve umudun aracı rolünün incelenmesi. Yüksek Lisans Tezi, Hacettepe Üniversitesi, Sosyal Bilimler Enstitüsü, Ankara.

Erdem, Ş., \& Kabasakal, Z. (2015). Psikolojik iyi olma ve yetişkin bağlanma boyutları. Eğitim ve Öğretim Araştırmaları Dergisi, 4(1), 82-90.

Ergün-Başak, B. (2012).Düşük gelirli ailelerden gelen üniversite öğrencilerinin öz duyarlık, sosyal bağlılık, iyimserlik ve psikolojik sağlamlık düzeyleri arasındaki ilişkiler. Doktora tezi. Anadolu Üniversitesi Eğitim Bilimleri Enstitüsü, Eskişehir.

Friborg O, Hjemdal O, Rosenvinge J.H., \& Martinussen, M. (2003) A new rating scale for adult resilience: what are the central protective resources behind healthy adjustment? Int J Methods Psychiatr Res, 12, 65-76.

Gözübüyük, N. (2015). Okul öncesi dönem çocuklarında davranış sorunlarının annebaba tutumu ve öz-kontrol ile ilişkisinin incelenmesi. Yüksek Lisans Tezi. Adnan Menderes Üniversitesi Sosyal Bilimler Enstitüsü, Aydın.

Gresham, F.M. \& Reschly, D.J. (1987). Dimensions of social competence. method factors in the assessments of adaptive behavior, social skills and peer acceptance. Journal of School Psychology, 25(4), 367-81.

Güler-Yazıcı, E. (2017). Beliren yetişkinlerin psikolojik dayanıkılık düzeylerinde yordayıcı değişkenler olarak yaşam doyumu ve yalnızlık. Yüksek Lisans Tezi. Necmettin Erbakan Üniversitesi Eğitim Bilimleri Enstitüsü, Konya.

Gülyüksel-Akdağ F. \& Cihangir-Çetinkaya, Z. (2014). Evli bireylerde psikolojik iyi oluşun yordanması. Mersin Üniversitesi Eğitim Fakültesi Dergisi, 11(3), 646662. DOI: $10.17860 /$ efd.67613

Hanton, S., Evans, L., \& Neil, R. (2002). Hardiness and the competitive trait anxiety repsonse. Anxiety, Stress and Coping, 16(2), 167-184. 
Hartup, W.W. (1996). The company they keep: Friendships and their developmental significance. Child Development, 67(1), 1-13.

Işık, M. (2007). Anasınıfına devam eden beş-altı yaş çocuklarına sosyal uyum ve beceri ölçeğinin uyarlanması ve uygulanması. Yüksek Lisans Tezi. Gazi Üniversitesi, Eğitim Bilimleri Enstitüsü, Ankara.

İlhan, T. (2017). Ebeveynlerin duygu sosyalleştirme stratejileri ile çocukların sosyal yetkinlik düzeyleri arasındaki ilişki. Yüksek Lisans Tezi, Hacettepe Üniversitesi Eğitim Bilimleri Enstitüsü, Ankara.

Karabacak, A. (2016). Evli bireylerin bağlanma stilleri, psikolojik iyi oluşları ve evlilik uyumları arasındaki ilişkinin incelenmesi. Yüksek Lisans Tezi, Atatürk Üniversitesi Eğitim Bilimleri Enstitüsü, Erzurum.

Karabacak, A. (2017). Beliren yetişkinlik dönemindeki bireylerde ilişkilerle ilgili bilişsel çarpıtmalar ve psikolojik iyi oluş arasındaki ilişkinin incelenmesi. International Journal of Social Sciences and Education Research, 3(2), 425-433.

Karacaoğlu, K., \& Köktaş, G. (2016). Psikolojik dayanıklılık ve psikolojik iyi olma ilişkisinde iyimserliğin aracı rolü: hastane çalışanları üzerine bir araştırma. İş ve Insan Dergisi, 3(2), 119-127.

Karadeniz-Akdoğan, K. (2017). 36-72 aylık çocukların sınıf ortamındaki istenmeyen davranışlarının incelenmesi. Yüksek lisans tezi, Ankara Üniversitesi Eğitim Bilimleri Enstitüsü, Ankara.

Karaırmak, Ö. (2006). Psikolojik sağlamlık, risk faktörleri ve koruyucu faktörler. Türk Psikolojik Danışma ve Rehberlik Dergisi, 3(26), 129-142.

Karaırmak, Ö., \& Siviş-Çetinkaya, R. (2011). Benlik saygısının ve denetim odağının psikolojik sağlamlık üzerine etkisi: Duyguların aracı rolü. Türk Psikolojik Danışma ve Rehberlik Dergisi, 4 (35), 30-43.

Karasar, N. (2017). Bilimsel araştırma yöntemi: Kavramlar ilkeler teknikler (32. Baskı). Ankara: Nobel Akademik Yayıncılık.

Keleş, H.N. (2017). Anlamlı iş ile psikolojik iyi oluş ilişkisi. The Journal of Happiness \& Well-Being, 5(1), 154-167.

Keyes, C.L., Shmotkin, D., \& Ryff, C. D. (2002). Optimizing well-being: The empirical encounter of two traditions. Journal of Personality And Social Psychology, 82(6), 1007-1022.

Kılıç, Ş.D. (2014). Üniversite öğrencilerinin yalnızlık ve psikolojik dayanıklılıklarının incelenmesi. Yüksek Lisans Tezi. Atatürk Üniversitesi, Eğitim Bilimleri Enstitüsü, Erzurum.

Klag, S., \& Bradley, G. (2004). The role of hardiness in stress and illness: An exploration of the effect of negative affectivity and gender. British Journal of Health Psychology, 9, 137-161. 
Kotler, J.C. \& McMahon, R.J. (2002). Differentiating anxious, aggressive, and socially competent preschool children: validation of the Social Competence and Behavior Evaluation-30 (parent version). Behav. Res. Ther., 40(8), 947-59.

Kuyumcu, B. (2012). Türk ve İngiliz üniversite öğrencilerinin psikolojik iyi oluş, duygusal farkındalık ve duygularını ifade etmelerinin ülke ve cinsiyet değişkenlerine göre incelenmesi. Erzincan Üniversitesi Eğitim Fakültesi Dergisi, 2, 1-24.

LaFreniere, P.J., \& Dumas, J.E. (1996). Social competence and behavior evaluation in children ages 3 to 6 years: The short form (SCBE-30). Psychological Assessment, 8(4), 369-377.

Neff, K.D. \& McGehee, P. (2010) Self-compassion and Psychological Resilience Among Adolescents and Young Adults, Self and Identity, 9(3), 225-240, DOI: 10.1080/15298860902979307

Olcay, O. (2008). Bazı kişisel ve ailesel değişkenlere göre okul öncesi dönemdeki çocukların sosyal yetenekleri ve problem davranışlarının analizi. Yüksek Lisans Tezi. Selçuk Üniversitesi, Sosyal Bilimler Enstitüsü, Konya.

Ong A.D., Bergeman, C.S., Bisconti, T.L., Wallace, K.A. (2006). Psychological resilience, positive emotions, and successful adaptation to stress in later life. Journal of Personality and Social Psychology, 91(4), 730-749. DOI: 10.1037/0022-3514.91.4.730

Öneren-Şendil, Ç. (2010), 5-6 yaş çocuklarında sosyal yetkinlik ve davranış sorunlarının akran kabulü, mizaç ve cinsiyet açısından incelenmesi. Yüksek Lisans Tezi, Orta Doğu Teknik Üniversitesi, Sosyal Bilimler Enstitüsü, Ankara.

Özer, E. \& Deniz, M. E. (2014). Üniversite öğrencilerinin psikolojik sağlamlık düzeylerinin duygusal zeka açısından incelenmesi. Illköğretim Online Dergisi, 13(4), 1240-1248.

Özyürek, A. (2015). Okul öncesi çocukların sosyal beceri düzeyleri ile anne tutumları arasındaki ilişkinin incelenmesi. Milli Eğitim Dergisi, 206, 106-120.

Rose-Krasnor, L. (1997). The nature of social competence: A theoretical Review. Social Development, 6(1), 111-135.

Ryff, C.D. (1995). Psychological well-being in adult life. Journal of Current Directions in Psychological Science, 4(4), 99-104 https://doi.org/10.1111/14678721.ep10772395

Sağ, B. (2016). Erken dönem uyumsuz şemalar ve pozitif algının psikolojik dayanıklılık depresyon ve psikolojik iyi oluş arasındaki ilişki. Yüksek Lisans Tezi. Maltepe Üniversitesi, Sosyal Bilimler Enstitüsü, İstanbul.

Slaski, M. \& Cartwright, S. (2002). Health, performance and emotional intelligence: An exploratory study of retail managers. Stress and Health, 18(2), 63-68. 
Souri, H., \& Hasanirad, T. (2011). Relationship between resilience, optimism and psychological well-being in students of medicine. Procedia-Social and Behavioral Sciences, 30, 1541-1544.

Staudinger, U.M., Freund, A.M., Linden, M., \& Maas, I. (1999). Self, personality, and life regulation: Facets of psychological resilience in old age. In P. B. Baltes \& K. U. Mayer (Eds.), The Berlin Aging Study: Aging from 70 to 100 (pp. 302-328). New York, NY, US: Cambridge University Press.

Tavşancıl, E. (2005). Tutumların ölçülmesi ve SPSS ile veri analizi. Ankara: Nobel Basımevi.

Telef, B. B. (2013). Psikolojik iyi oluş ölçeği: Türkçeye uyarlama, geçerlik ve güvenirlik çalışması. Hacettepe Üniversitesi Eğitim Fakültesi Dergisi, 28(3), 374-384.

Telef, B.B., Uzman, E. \& Ergün, E. (2013). Öğretmen adaylarında psikolojik iyi oluş ve değerler arasındaki ilişkinin incelenmesi. Turkish Studies, 8(12), 1297-1307.

Terzi, Ş. (2005). Öznel iyi olmaya ilişkin psikolojik dayanıklıık modeli. Doktora Tezi. Gazi Üniversitesi, Eğitim Bilimleri Enstitüsü, Ankara.

Thompson, R.A. (2006). Attachment in early years and effects on later development. 14. Ulusal Psikoloji Kongresi, 6-8 Eylül 2006, Hacettepe Üniversitesi, Ankara.

Topçu, F. (2017). Üniversite öğrencilerinin psikolojik dayanıklılık düzeylerinde beş faktör kişilik özelliklerinin yordayıcı etkisinin incelenmesi. Yüksek Lisans Tezi. Fatih Sultan Mehmet Vakıf Üniversitesi Sosyal Bilimler Enstitüsü, İstanbul.

Ulu, M. (2018). İlahiyat fakültesi öğrencilerinin psikolojik iyi oluşları ile değer yönelimleri arasındaki ilişki. Sakarya Üniversitesi Ilahiyat Fakültesi Dergisi, 20(37), 183-215. DOI: http://dx.doi.org/10.17335/sakaifd.414012

Ülker Tümlü, G., \& Recepoğlu, E. (2013). Üniversite akademik personelinin psikolojik dayanıkılık ve yaşam doyumu arasındaki ilişki. Yükseköğretim ve Bilim Dergisi, 3(3), 205-213.

Verschueren, K., Buyck, P., \& Marcoen, A. (2001). Self-representations and socioemotional competence in young children: A three-year longitudinal study. Developmental Psychology, 37(1), 126-134.

Yaşar-Ekici, F. (2017). Okul öncesi eğitim kurumlarındaki aile katıım çalışmalarına katılan ve katılmayan ailelerin çocuklarının sosyal beceri ve problem davranışları arasındaki ilişki. Hitit Üniversitesi Sosyal Bilimler Enstitüsü Dergisi, 10(1), 543-562. DOI: 10.17218/hititsosbil.299033

Yılmaz, D. (2017). Yalnızlık duygusu, psikolojik dayanıklılık ve anksiyete düzeyleri açısından ev hanımlarıyla çalışan kadınların karşılaştırılması. Yüksek Lisans Tezi. Üsküdar Üniversitesi Sosyal Bilimleri Enstitüsü, İstanbul. 